\title{
Evaluating Strategies for Ranching in the 21st Century: The New Market Place
}

\section{By Doug Wilmeth, Brian Bertelsen, and Dan Probert}

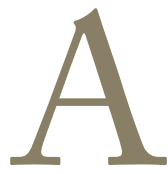

new marketplace exists in today's beef industry. It is not your parent's cattle industry any more, and it is changing at an ever-increasing rate. For those who choose to participate, there are more marketing opportunities available to them than ever before in the history of the beef cattle industry. Twenty years ago, few if any alternatives to the commodity cattle markets existed in the United States. Today, numerous consumerbased programs operate successfully in the marketplace, including 48 programs that have been certified by the USDA. ${ }^{1}$ Although the number of these marketing programs fluctuates, the trend is growing. These programs and the companies behind them offer new strategic alternatives for ranchers to consider as they evaluate changes in the cattle business and how they impact their operations. Value-based programs can provide ranchers opportunities to capture value from investments they have made in herd health, genetic selection, and overall management. Many of these programs also provide ways to mitigate risk and increase profits. They are designed to provide links from the rancher to the ultimate customer, the consumer of beef. These links can create opportunities for additional consumer dollars to travel down the supply chain to be distributed among all of the segments of the industry, based on the value each segment contributes to the product. In these systems, consumer demand for specific products is the economic driver of production. In a value-based marketing system, this manifests itself on the ranch in the decisions made regarding genetics, breeding, herd health, feed, grazing, and other production practices, as the rancher attempts to respond to consumer demand. In the current dynamic cattle industry, producing commodity cattle and hoping to find markets for them is a strategy that carries with it levels of risk that are arguably higher than many of those available in these emerging markets.

\section{What is a Value-Based Marketing Alliance in the Cattle Industry?}

A value-based marketing program is a system of marketing a specific line of beef products to targeted consumers, which in turn passes value down the production chain. This process requires that markets be identified and specific products be targeted for those same markets. An alliance is defined as "an association to further the common interests of the members." A value-based marketing alliance, then, is a group of individuals whose common interest is to target a specific array of beef products to identifiable consumers. The value received from the consumer is then divided between the participants of the alliance. The goals of the marketing alliance are threefold. First, to capture value for the participants in the alliance by targeting consumers who are willing to pay higher prices for beef that possesses specific qualities. Second, to increase value in the marketplace by differentiation. Third, to pass the increased and captured value through the production chain in a way that reflects each member's contribution and risk. Typically, membership in valued-based marketing alliances reflects most, but not necessarily all, segments of the beef production system.

Value-based marketing alliances are usually based on some identifiable uniqueness. This could be types or characteristics of the products offered, or things such as geographic region, or some membership requirement. One example is a group of beef producers selling beef from cattle produced in an organic production system or in a similar, but less restrictive, system referred to as "natural." Other alliances are made up of individuals from a specific geographic 


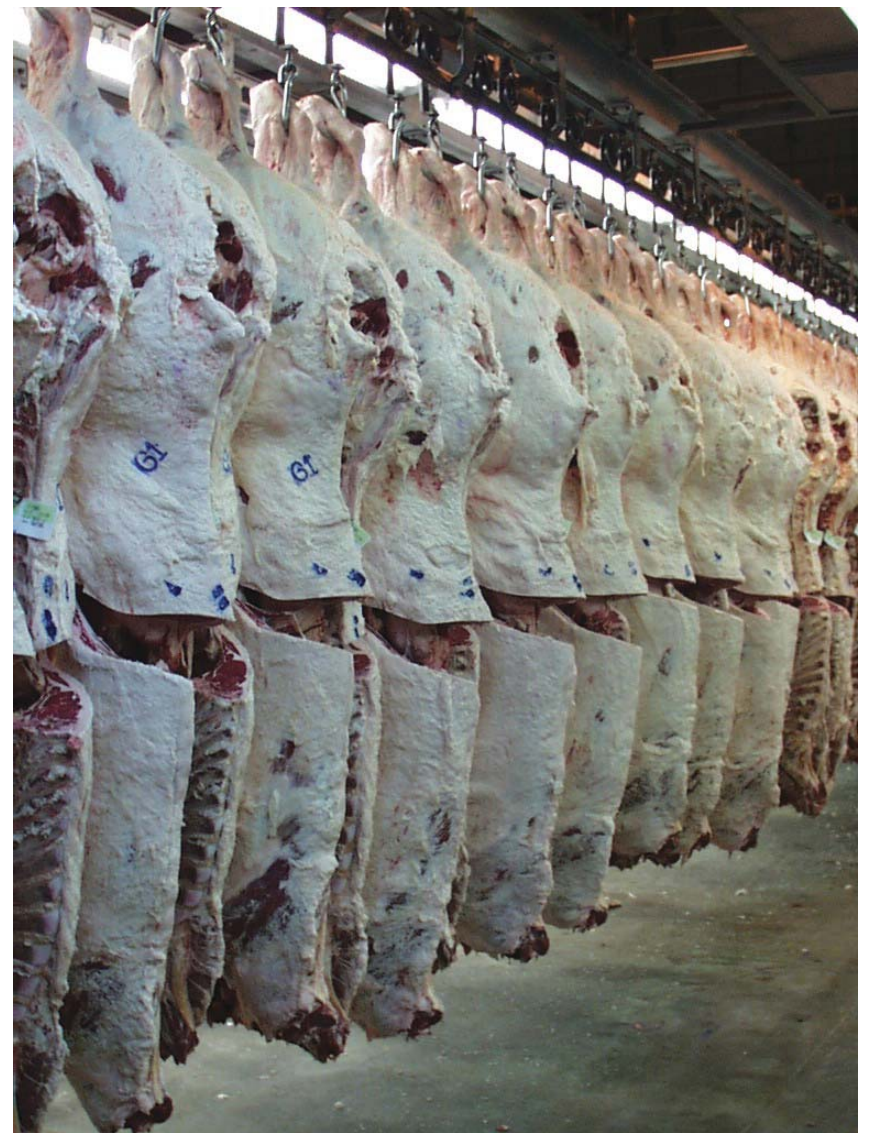

region, or other alliances might require members to produce a specific breed of cattle, or to produce cattle in a specific type of system. Frequently, alliances require that the production system requirements result in specific beef carcass characteristics. They also might require some level of financial investment in the alliance.

The beef carcass targets for value-based marketing alliances usually fall into one of two categories. One is a requirement that the carcass have relatively high levels of intramuscular fat, commonly known as marbling, with adequate muscling. The second major type of value-based marketing alliance program is for qualifying carcasses to be well-muscled and very lean. ${ }^{3}$ However, some value-based marketing alliances differentiate themselves by producing cattle that meet certain production-based specifications. In summary, the major categories that value-based marketing alliances are as follows:

- Those that market beef that is highly marbled and has adequate muscling.

- Those that market beef that is very lean from heavily muscled carcasses.

- Those that sell beef raised in an organic production system.

- Those that sell beef raised in a natural production system.
- Those that sell beef from a specific breed or type of cattle.

- Those that sell beef raised in a specific geographic region.

Some value-based marketing alliances have requirements that fit in several of the above categories.

The types of business structures under which value-based marketing alliances operate reflect the goals of the participants. Some operate as cooperatives, and others function as traditional corporations. Rancher participation varies from being a contracted supplier to a stockholder. Value-based marketing alliances all differ substantially and Table 1 has references that will aid in a search for information concerning them.

\section{What Ranchers Need to Know}

It should be clear, then, that for a rancher to successfully participate in a value-based marketing alliance, there are three basic requirements of management. First, a rancher might have to successfully subscribe to specific production processes and be able to provide verification that will hold up under the scrutiny of an audit of those processes. Secondly, the ranch manager should know and understand the carcass characteristics of the cattle they are raising and to make a realistic assessment of the opportunity for their cattle to profitability fit into specific programs. And the third, and perhaps most important, is that the management skills necessary for successful participation in a value-based marketing alliance are clearly understood, as well as the financial costs and benefits associated with participation or membership. Process verification is a new concept to an industry that has operated on the strength of a handshake for the last 125 years. In fact, in the high-tech world of 2007, the handshake is often replaced by verbal confirmation over a phone, based on the strength of personal reputations and relationships; however, this is not adequate

\section{Table 1. Resources for finding value-based marketing alliances}

USDA

www.ams.gov/lsg/certprog/certbeef.htm ${ }^{1}$

Industry alliance listings

www.beefmagazine.com/images/07BeefAlliance.pdf ${ }^{4}$

Local resources

Extension agent

Internet search engine-key words

Livestock market alliances

Branded beef programs

USDA certified beef products 
for value-based programs. Today, participation in many value-based marketing alliances requires written production protocols and verifiable written records of compliance to those protocols. Some of these are associated with USDA certification, whereas others are driven by the marketplace. Examples of these process requirements include premise ID, individual animal ID, herd and individual health records, feed records, ownership and location transfer records, environmental management records, and breeding and pedigree records. Some value-based marketing alliances require thirdparty annual audits of required records and annual on-site inspections. Although these types of verification practices are common for the classification of the various levels of certification in the dairy industry, they can represent a challenging hurdle for many beef cattle operations.

If a rancher doesn't already know the carcass characteristics of the cattle they produce, there are several ways a ranch manager can learn about them. A rancher can ask the feedlot operator who has finished the rancher's cattle in the past for the historic feedlot performance records as well as the records of the cattle's carcass characteristics. Another option is to retain ownership of the cattle through the finishing period of the production system and market the cattle in one of many pricing grids offered by the packing industry. The feedlot performance records and carcass information is then the property of the rancher. Many feedlots are willing to share ownership of a rancher's cattle, provide financing for the cattle and the feed, and assist the rancher in risk management as well as marketing decisions. An option that has less associated risk and disruption is to participate in one of many programs designed to allow ranchers to test the marketplace and get feedlot performance and carcass information on a sample of their cattle. Often referred to as "ranch to rail" or "value discovery" programs, these programs are usually associated with the Cooperative Extension System at Land Grant Universities and can be found in many states (see sidebar). It is important to keep in mind that participation in these programs is with a small sample of a rancher's cattle. The associated feedlot performance and carcass characteristic information represents just that, a sample. That being said, these programs have proven to be extremely valuable to thousands of participants across the United States. The worksheet in Table 2 is designed to help producers determine if their cattle fit the program they are evaluating. ${ }^{5}$

Whether or not the levels of financial risk and rewards are acceptable is perhaps the most critical decision to make in consideration of participating in value-based marketing alliances. The worksheets in Table 3 and Table 4 are designed to assist interested individuals evaluate this important decision. ${ }^{5}$ Financial rewards from participation can come in several forms, including shareholder dividends, appreciation of the value of the stock of the company held by the rancher, and increased net income from the sale of their cattle through the marketing alliance. However, with investment comes risk. If the marketing alliance is unprofitable, a rancher's investment can decline in value, and the sale of the cattle through the alliance can reduce ranch net income.

\section{What is Grid Marketing?}

Grid marketing should not be confused with a value-based marketing alliance. Grid marketing is a pricing tool used by packing companies and value-based marketing alliances to determine a carcass's value to a specific market. It is an alternative to pricing fed cattle on the hoof. It reduces risk for the packing company and value-based marketing alliances, and is a powerful tool for passing market signals down the production chain. A pricing grid is dynamic, because supply and demand constantly adjusts the value of specific beef carcasses in the marketplace. The change in value is reflected in the grid marketing matrix in two ways. First, the overall supply of cattle and consumer demand for beef is reflected in the grid's base price. These base prices are usually adjusted weekly. They are specific to individual packing plants, due to differences in supply local to each plant, and to the individual plant's unique economic factors, such as cost structure and distance to the specific markets for their product. The second way in which a grid pricing matrix changes in response to the marketplace is in the premiums and discounts it pays for specific carcass characteristics. These premiums and discounts vary greatly between value-based marketing programs and between the various branded product lines in the meat industry. Although the difference in the premiums and discounts for various attributes of carcasses receives a great deal of attention, in the consideration of the decision to participate in a value-based marketing alliance, the base price is of critical importance.

\section{Two Examples of Value-Based Marketing Alliances}

Two very different examples of value-based marketing alliances are Country Natural Beef (CNB) of Antelope, Oregon, and US Premium Beef (USPB) of Kansas City, Missouri. Both have developed links that connect them directly with their retail customers. Both have passed many litmus tests of success, including profitability, longevity, and growth.

$\mathrm{CNB}$ is a rancher-based program that was started 20 years ago in eastern Oregon. Its 14 original rancher-owners were struggling financially while selling their cattle on the commodity cattle market. The original members knew they had a healthy product raised without artificial inputs on environmentally sustainable family ranches. However, they felt that they needed to develop a link that would connect them with a customer that wanted their beef product and was willing to pay a premium for its attributes. There are now 76 families in eight western states and Hawaii who market their cattle under the CNB alliance. Ranchers 
Resources for feedlot performance and carcass data

\section{Arizona \\ Robin L. Grumbles \\ 928-753-3788}

\section{Arkansas Steer Feedout Program \\ University of Arkansas \\ Brett Barham \\ 501-671-2162}

\section{Beef Empire Steer Test}

Kansas State University

Ron Hale

620-275-9164

\section{Colorado}

David Coburn

Sterling, CO 80751

970-522-3200

\section{Eastern North Dakota Cattle Feedout \\ North Dakota State University \\ Karl Hoppe \\ 701-652-2951}

\section{Georgia Beef Challenge \\ University of Georgia-Athens \\ Patsi Cannon \\ 229-386-3683}

\section{Idaho A-Z Retained Ownership \\ University of Idaho \\ Gordon C. Keetch \\ 208-253-4279}

\section{Indiana Beef Evaluation \\ Purdue University \\ Kern Hendrix \\ 765-494-4832}

\section{American Brahman Breeders \\ Chris Shivers \\ 713-349-0854}

\section{Virginia Retained Ownership}

Virginia Tech University

Scott Greiner

540-231-9159

\section{Nebraska Beef Evaluation \\ University of Nebraska-Lincoln \\ Rob Eirich \\ 308-874-2705}

\section{South Dakota Calf-Value Discovery}

South Dakota State University

Cody Wright

605-688-5448

\section{Missouri Steer Feedout Program \\ University of Missouri \\ Eldon Cole \\ 417-466-3102}

\section{New Mexico Ranch to Rail}

New Mexico State University

Manny Encinia

505-374-2566

\section{Resources (continued)}

New York Feedlot \& Carcass Program

Cornell University

Mike Baker

607-255-5923

\section{South Carolina Beef Evaluation}

Clemson University

Rusty Thomson

864-429-7062

\section{Kansas Angus Association}

Carcass Data Project

Mark Lampe

620-874-0258

\section{Kentucky}

University of Kentucky

Doug Shepherd

270-765-4121

\section{Tri-County Steer Carcass Futurity}

lowa State University

Darrell Busby

712-769-2600

\section{Minnesota Carcass Merit Program}

University of Minnesota

Dr. Alfredo Dicostanzo

612-624-1272

\section{Oklahoma Steer Feedout}

Oklahoma State University

Kent Barnes

918-686-7800

\section{Sandhills Cattle Association}

Performance \& Carcass Contest

Ronna Morse

402-376-2310

\section{Santa Gertrudis Breeders International}

Ervin Kaatz

Kingsville, Texas

361-592-9357

\section{Tennessee Beef Evaluation}

University of Tennessee

Emmit Rawls

865-974-7271

\section{Wyoming Beef Evaluation}

University of Wyoming

Steve Paisley

307-760-5541

must comply with a third party audit of CNB's standards of careful land stewardship, and of raising cattle without the use of antibiotics, growth hormones, or feed additives. Every rancher member's cattle are sent to a single feedyard at Beef Northwest Feeders in Boardman, Oregon. The cattle are fed an average of $92-94 \mathrm{~d}$, as opposed to the $120-140 \mathrm{~d}$ industry average. After the finishing period, they are custom processed at $\mathrm{AB}$ Foods in Toppenish, Washington. The CNB cattle provide a smaller carcass, weighing between 275 and $325 \mathrm{~kg}$ (600-700 pounds). These carcasses also 


\section{Table 2. Value-based marketing: do my cattle fit?}

Answering the following questions can help determine if the value-based marketing system you are evaluating is a good fit with your beef production system.

\begin{tabular}{|c|c|c|}
\hline$\stackrel{\infty}{\Perp}$ & 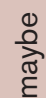 & $\stackrel{\circ}{\complement}$ \\
\hline 0 & O & O \\
\hline $\mathrm{O}$ & 0 & 0 \\
\hline 0 & 0 & 0 \\
\hline 0 & 0 & 0 \\
\hline 0 & 0 & 0 \\
\hline $\mathrm{O}$ & $\mathrm{O}$ & $\mathrm{O}$ \\
\hline 0 & 0 & 0 \\
\hline
\end{tabular}

1. My breeding program fits the requirements of the program I am evaluating.

2. I have historical carcass data on my cattle.

3. My cattle produce carcasses that fit the requirements of the program.

4. I have historical feedlot data on my cattle.

5. My cattle's feedlot performance indicates they can meet requirements of the program.

6. My health program matches or can be adapted to the requirements of the program.

7. I can meet the specific feedlot or delivery requirements of the program.

Evaluation: If one or more are answered no, your cattle probably will not fit and may cost you money or not return the expected income. A maybe indicates an area where more information is needed. If all are yes, then the program looks like a good fit.

Adapted from Dunn and Boggs 1997.

\section{Table 3. Value-based marketing: can I handle the financial risk?}

The following exercise is designed to help you make an informed decision about your ability to handle the risk associated with extending ownership and participating in a value-based marking system (VBMS) with a selected group of your feeder cattle.

\begin{tabular}{|c|c|c|c|}
\hline$\stackrel{\infty}{\infty}$ & $\frac{\mathbb{\Xi}}{\stackrel{\text { ฮ }}{\varepsilon}}$ & 읃 & \\
\hline $\mathrm{O}$ & $\mathrm{O}$ & $\mathrm{O}$ & 1. Do I have a current analysis of my financial position? \\
\hline $\mathrm{O}$ & $\mathrm{O}$ & $\mathrm{O}$ & $\begin{array}{l}\text { 2. The revenue generated by the sale of my feeder cattle is not necessary to meet financial } \\
\text { obligations. }\end{array}$ \\
\hline $\mathrm{O}$ & $\mathrm{O}$ & $\mathrm{O}$ & $\begin{array}{l}\text { 3. Will my cattle operation be profitable if I sell my feeder cattle at the normal or traditional } \\
\text { marketing time? }\end{array}$ \\
\hline $\mathrm{O}$ & $\mathrm{O}$ & $\mathrm{O}$ & $\begin{array}{l}\text { 4. I understand the base price, quality grade, yield grade, and carcass premiums and discounts } \\
\text { associated with the VBMS I am evaluating. }\end{array}$ \\
\hline $\mathrm{O}$ & $\mathrm{O}$ & $\mathrm{O}$ & $\begin{array}{l}\text { 5. I have completed a partial budget for the decision to enter into a VBMS that show profit } \\
\text { potential. }\end{array}$ \\
\hline $\mathrm{O}$ & $\mathrm{O}$ & $\mathrm{O}$ & $\begin{array}{l}\text { 6. If participating in this VBMS causes me to lose money, my base operation will not be at } \\
\text { financial risk. }\end{array}$ \\
\hline $\mathrm{O}$ & $\mathrm{O}$ & $\mathrm{O}$ & 7. Does the potential profit gained by participation outweigh the financial risk? \\
\hline $\mathrm{O}$ & $\mathrm{O}$ & $\mathrm{O}$ & 8. Do I have the potential to use risk management tools to offset anticipated risk? \\
\hline $\mathrm{O}$ & $\mathrm{O}$ & $\mathrm{O}$ & $\begin{array}{l}\text { 9. I understand that changing the breeding or management of my cattle to meet specific } \\
\text { requirements of this VBMS might impact my financial situation. }\end{array}$ \\
\hline $\mathrm{O}$ & $\mathrm{O}$ & $\mathrm{O}$ & 10. The ownership requirements of the program are acceptable. \\
\hline
\end{tabular}

Evaluation: If one or more are answered no or maybe, then acquire more information. If all are yes, then proceed with your evaluation.

Adapted from Dunn and Boggs 1997..$^{5}$ 
have leaner and smaller cuts of meat than would be typical in commodity beef. Every year CNB updates an average cost of production model that is the basis for how they set the price of their meat to their consumers. It does not cost anything to belong to CNB. There are no up-front payments to get in or annual fees to pay. CNB offers a way to set a price that is stable and doesn't fluctuate with the commodity market. The company has grown steadily, as has the reputation of its natural beef, which has attracted a cadre of loyal customers. Last year CNB shipped 40,000 head to market. CNB markets directly to natural food stores. Whole Foods of Austin, Texas, buys approximately $60 \%$ of CNB's beef, and they in turn market the beef mainly on the west coast. Other major buyers include 100 restaurants; New Seasons natural food stores in Portland, Oregon; Bon Appétit, which supplies colleges and hospitals; and Burgerville, a northwest burger chain that prepares burgers only with fresh beef.

USPB is a fully integrated, $100 \%$ producer-owned beef marketing company. These owners, of which there are more than 2,100, are producers from every segment of the cattle industry, including seedstock, commercial ranchers, backgrounders, and feedlots. It markets many different branded beef labels such as Certified Angus, Certified Hereford, and Black Canyon Angus, and three different natural brands, to their retail customers. USPB is the majority owner of National Beef Packing Company (NBPC), which is the fourth largest packer in the United States. They have plants in Dodge City and Liberal, Kansas, and one plant in Brawley, California. National Beef Packing

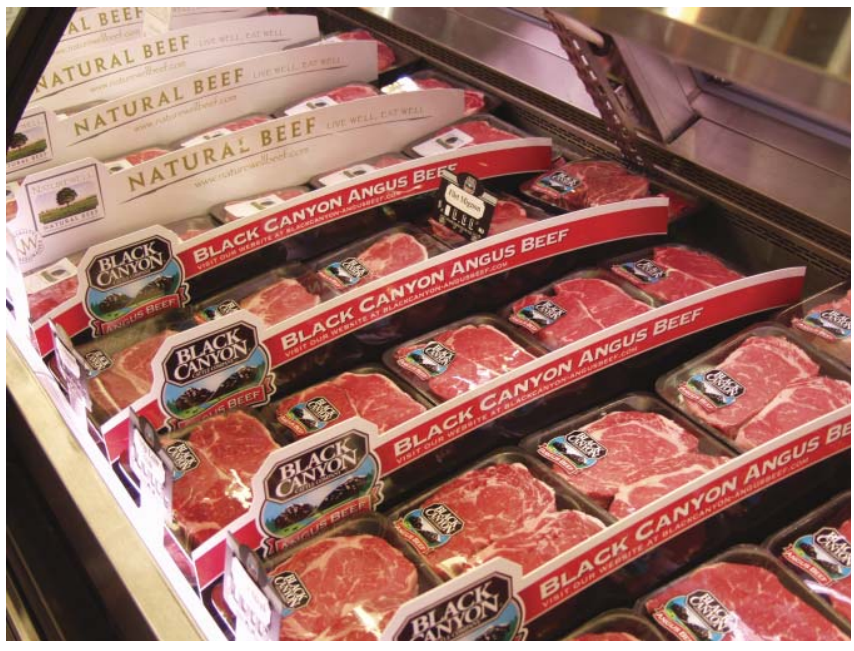

Company sells value added, branded beef products to customers in retail, restaurants, and distributors all over the world. It includes case-ready products to customers such as Wal-Mart. It also includes Kansas City Steaks, a company that cuts steaks for some of the largest restaurant chains. They also market beef directly to the consumer via the internet, toll-free phone orders, and the QVC shopping network. Cattle delivered by USPB producers are priced on value-based grids where the premiums offered are directly related to the prices paid by customers of NBPC for the various products and brands. The value-based grid is the vehicle that connects the consumer demand for specific products, all the way back to the rancher.

Table 4. Financial evaluation worksheet that can be used to help determine the financial feasibility of a value-based marketing alliance (make these calculations on a per head basis)

\begin{tabular}{|c|c|c|c|}
\hline Projected income & & Projected expenses & \\
\hline A. Market Value & & A. Feeder value & \\
\hline B. $+/-$ carcass premium/discount & & B. Feed & \\
\hline C. Cost savings & & C. Yardage & \\
\hline D. Marketing & & D. Financing & \\
\hline \multirow{5}{*}{$\begin{array}{l}\text { E. Management (e.g., value-based } \\
\text { marketing system might restrict } \\
\text { use of certain products) }\end{array}$} & & E. Veterinary & \\
\hline & & F. Death loss & \\
\hline & & G. Transportation & \\
\hline & & H. Entry fees & \\
\hline & & $\begin{array}{l}\text { I. Performance limitation (e.g., not using an } \\
\text { implant reduces final weight gain) }\end{array}$ & \\
\hline Total revenue & & Total expenses & \\
\hline \multicolumn{4}{|c|}{ Net income $=$ total revenue - total expenses } \\
\hline Source: Dunn and Boggs $1997 .{ }^{5}$ & & & \\
\hline
\end{tabular}




\section{Summary and Concluding Thoughts}

Value is derived from a marketplace by having the right product, at the right time, in the right place, in the right quantity, at the right price. The demand for consumerfriendly, quality differentiated beef products in the marketplace is steadily and dramatically increasing. Meeting this demand is of primary importance to the beef cattle industry. ${ }^{6}$ One specific method of meeting this demand and capturing the associated increased value has been the formation of value-based marketing alliances. These alliances, although varying greatly in their business structure and the markets they target, provide ranchers with viable options for marketing their cattle. Given new and changing scenarios in the cattle industry, such as market volatility and the emergence of the ethanol industry, evaluating marketing programs that have the potential to mitigate risk and increase profits should be of primary importance to ranchers. Because value-based marketing alliances have proven to have this potential, they represent an important opportunity for ranchers to consider as they develop strategic plans for the future. This consideration should include answering several key questions. First, do the benefits of participating in value-based marketing alliances outweigh the associated costs and risks? Secondly, are the requirements for participation in a value-based marketing alliance in alignment with the rancher's production systems and the carcass characteristics of their cattle? Third, will participation in a valuebased marketing alliance help a rancher achieve the overall vision they have set for their ranching operation? If the answers to these questions are yes, then participating in this "new marketplace" might be a strategy for consideration in the development of a ranch's strategic plan.

\section{References}

1. USDA Certified Beef Programs. 2008. Available at: http://www.ams.usda.gov/lsg/certprog/certbeef.htm. Accessed 15 January 2008.

2. The New American Webster's Dictionary. 4th ed. 2006. New York, NY, USA: New American Library. 843 p.

3. Sartwelle, J. D., E. E. Davis, J. Mintert, and R. Borchardt. 2000. Beef cattle marketing alliances. College Station, TX, USA: Texas Agricultural Extension Service, Texas A\&M University System. L-5356. 3 p.

4. Industry Alliance Listings. 2008. Available at: http://www. beefmagazine.com/images/07BEEFAlliance.pdf. Accessed 15 January 2008.

5. Dunn, B. H., And D. Boggs. 1997. Value-based marketing systems and you, the producer. Brookings, SD, USA: South Dakota State University, Animal and Range Sciences Department. ESS 47 Beef Herd Management. 4 p.

6. NCBA Long Range Plan. 2008. Beef industry long range plan. Available at: http://www.longrangeplan.org. Accessed 15 January 2008.

Authors are Graduate Fellow, King Ranch Institute for Ranch Management, Kingsville, TX 78363,USA, jack.wilmeth@ tamuk.edn (Wilmeth); Director of Field Operations, US Premium Beef, Dodge City, KS 67801, USA (Bertelsen); and Rancher Member, Country Natural Beef, Vale, OR 97918, USA (Probert). 